\title{
The use of SMILES data to study ozone loss in the Arctic winter 2009/2010 and comparison with Odin/SMR data using assimilation techniques
}

\author{
K. Sagi ${ }^{1}$, D. Murtagh ${ }^{1}$, J. Urban ${ }^{1, \dagger}$, H. Sagawa ${ }^{2}$, and Y. Kasai ${ }^{2}$ \\ ${ }^{1}$ Department of Earth and Space Sciences, Chalmers University of Technology, Gothenburg, Sweden \\ ${ }^{2}$ National Institute of Information and Communications Technology, Tokyo, Japan \\ $\dagger$ deceased 14 August 2014
}

Correspondence to: K. Sagi (sagi@chalmers.se)

Received: 22 January 2014 - Published in Atmos. Chem. Phys. Discuss.: 24 March 2014

Revised: 4 November 2014 - Accepted: 11 November 2014 - Published: 8 December 2014

\begin{abstract}
The Superconducting Submillimeter-Wave LimbEmission Sounder (SMILES) on board the International Space Station observed ozone in the stratosphere with high precision from October 2009 to April 2010. Although SMILES measurements only cover latitudes from $38^{\circ} \mathrm{S}$ to $65^{\circ} \mathrm{N}$, the combination of data assimilation methods and an isentropic advection model allows us to quantify the ozone depletion in the 2009/2010 Arctic polar winter by making use of the instability of the polar vortex in the northern hemisphere. Ozone data from both SMILES and Odin/SMR (SubMillimetre Radiometer) for the winter were assimilated into the Dynamical Isentropic Assimilation Model for OdiN Data (DIAMOND). DIAMOND is an off-line wind-driven transport model on isentropic surfaces. Wind data from the operational analyses of the European Centre for Medium- Range Weather Forecasts (ECMWF) were used to drive the model. In this study, particular attention is paid to the cross isentropic transport of the tracer in order to accurately assess the ozone loss. The assimilated SMILES ozone fields agree well with the limitation of noise induced variability within the SMR fields despite the limited latitude coverage of the SMILES observations. Ozone depletion has been derived by comparing the ozone field acquired by sequential assimilation with a passively transported ozone field initialized on 1 December 2009. Significant ozone loss was found in different periods and altitudes from using both SMILES and SMR data: The initial depletion occurred at the end of January below $550 \mathrm{~K}$ with an accumulated loss of $0.6-1.0 \mathrm{ppmv}$ (approximately $20 \%$ ) by 1 April. The ensuing loss started
\end{abstract}

from the end of February between $575 \mathrm{~K}$ and $650 \mathrm{~K}$. Our estimation shows that $0.8-1.3 \mathrm{ppmv}(20-25 \%)$ of $\mathrm{O}_{3}$ has been removed at the $600 \mathrm{~K}$ isentropic level by 1 April in volume mixing ratio (VMR).

\section{Introduction}

According to many studies of stratospheric ozone $\left(\mathrm{O}_{3}\right)$, major ozone depletion inside the isolated polar vortex is caused by the formation of polar stratospheric clouds (PSCs) and the associated heterogeneous release of active chlorine species $(\mathrm{Cl}, \mathrm{ClO})$ (e.g. Solomon, 1999). However, in comparison with the Antarctic polar vortex, the Arctic vortex is less stable due to the propagation of planetary waves from the troposphere. Therefore, the periods during which the temperature inside the vortex go below the threshold for PSC formation are limited (WMO, 2011). These effects make the quantification of chemical ozone depletion in the Arctic generally more difficult.

The winter of 2009-2010 was colder than other winters in the last decade during January (e.g. Dörnbrack et al., 2012). Figure 1 indicates the minimum temperature $\left(T_{\min }\right)$ as a function of day of the year (DOY) derived from the European Centre for Medium-range Weather Forecasts (ECMWF) operational forecasts on the $500 \mathrm{~K}$ potential temperature (PT) surface at equivalent latitudes (EQL) greater than $70^{\circ} \mathrm{N}$. The $T_{\min }$ for the winter period of 2009/2010 was lower than $185 \mathrm{~K}$ from 1 January and became as low as $180 \mathrm{~K}$ on 7 


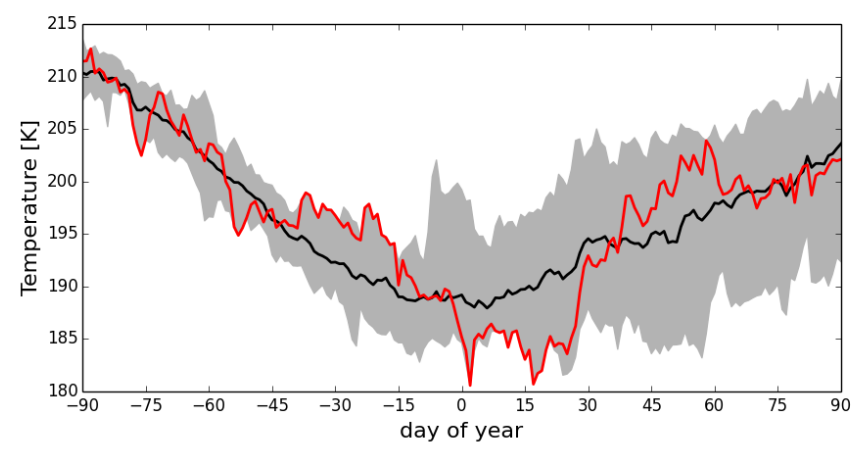

Figure 1. Minimum ECMWF temperature, $T_{\min }(\mathrm{K})$, at a potential temperature of $500 \mathrm{~K}$ inside the area where the equivalent latitude (EQL) is greater than $70^{\circ}$, corresponding to the area inside the Arctic polar vortex, as function of days of year ( 0 refers to 1 January). The black solid line shows the mean value for years 2001 to 2012. The red line is the $T_{\min }$ temporal evolution from 1 October 2009 to 31 March 2010. The shaded area encompasses the minimum/maximum $T_{\min }$ between 2001 and 2011.

January (see also Dörnbrack et al., 2012). Khosrawi et al. (2011) reported that strong denitrification caused by the formation of PSCs was observed during the synoptic cooling event in mid-January 2010. However, a sudden stratospheric warming (SSW) ended the coldest period after 19 January (Dörnbrack et al., 2012; Kuttippurath and Nikulin, 2012). SSWs are wintertime phenomena that are characterized by suddenly increasing temperatures and a reversal of the zonal wind (Scherhag, 1952). The planetary wave disturbance of the vortex with the occurrence of the SSW event makes this winter dynamically complicated.

SMILES (Superconducting Submillimeter-wave LimbEmission Sounder), a passive atmospheric sensor attached to the Japanese Experiment Module (JEM) on board the International Space Station (ISS), was developed by the Japan Aerospace Exploration Agency (JAXA) and the National Institute of Information and Communications Technology (NICT). SMILES used $4 \mathrm{~K}$ superconducting detector technology to measure high-precision vertical profiles of stratospheric and mesospheric species related to ozone chemistry. The instrument was operated from October 2009 until April 2010 when the local oscillator failed and provided atmospheric composition data typically within the latitude range of $38^{\circ} \mathrm{S}-65^{\circ} \mathrm{N}$ (Kikuchi et al., 2010).

The aim of this paper is to demonstrate the use of the high-sensitivity observations by SMILES to quantify polar ozone loss. However, it is still a challenge to use SMILES data to analyse the polar regions because of its limited latitude coverage. The Odin/SMR ozone has been also analysed in this study for comparison with SMILES ozone because this instrument also uses the limb sounding technique and has a long record of stratospheric ozone measurements starting in 2001. Figure 2 shows a typical observation map of SMILES and SMR and Table 1 summarizes the nominal

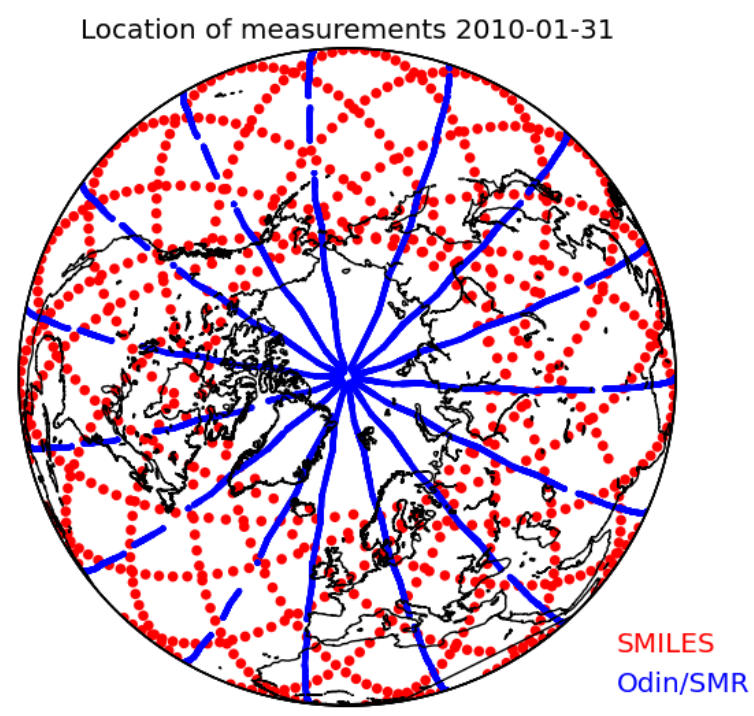

Figure 2. Geographical distributions of ozone observations from SMILES and Odin/SMR on 2010-01-31.

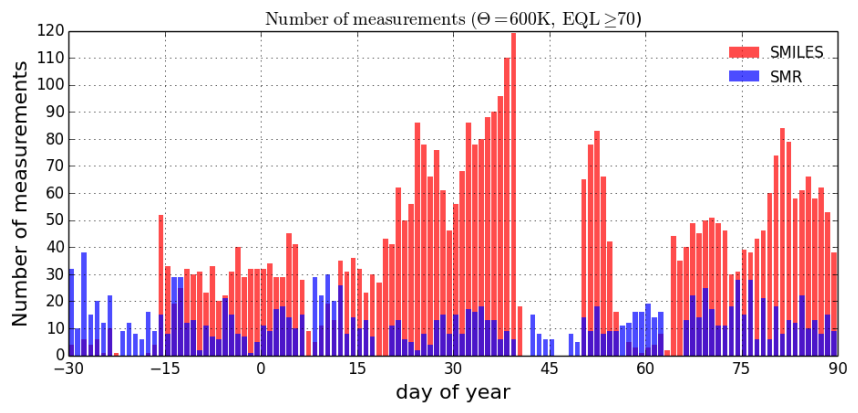

Figure 3. The number of measurements inside the area where the equivalent latitude is greater than $70^{\circ} \mathrm{N}$ on a potential temperature surface of $500 \mathrm{~K}$ against day of year ( 0 refers to 1 January). Note that only measurements with measurement response above a threshold of 0.85 are considered.

specification of both observations. The higher vertical scan rate of SMILES compared to SMR explains the larger number of measurements. In addition, the dynamical instability of this winter season, displacing the vortex to latitudes below $65^{\circ} \mathrm{N}$, permitted a considerable number of SMILES observations within the vortex. Thus SMILES made more measurements than SMR even in the vortex $\left(\mathrm{EQL} \geq 70^{\circ} \mathrm{N}\right)(\mathrm{see}$ Fig. 3). On the other hand, there are periods when SMILES measurements inside the vortex were not available due to ISS manoeuvres. In the first half of December, the field of view of the SMILES antenna was blocked by the ISS solar paddles, resulting in only a few useable measurements. Another period without measurements, in the middle of February, is due to the rotation of the ISS to dock with the space shuttle Endeavour. When the space shuttle was docked, the ISS was rotated by $180^{\circ}$ and SMILES looked towards the Southern Hemisphere. 
Table 1. Typical specification of the observations.

\begin{tabular}{|c|c|c|}
\hline Parameters & SMILES & SMR \\
\hline Orbit & non-sun-synchronous orbit & sun-synchronous orbit \\
\hline Inclination angle & $51.6^{\circ}$ & $98^{\circ}$ \\
\hline Altitude & $340-360 \mathrm{~km}$ & approximately $600 \mathrm{~km}$ \\
\hline Latitude coverage & $38^{\circ} \mathrm{S}-65^{\circ} \mathrm{N}$ & $82.5^{\circ} \mathrm{S}-82.5^{\circ} \mathrm{N}$ \\
\hline \multicolumn{3}{|l|}{ Parameters (data sampling) } \\
\hline Measurement geometry & limb scan & limb scan \\
\hline Scan altitude & $-20-120 \mathrm{~km}$ & $7-72 \mathrm{~km}$ \\
\hline Vertical sampling interval & approximately $2 \mathrm{~km}$ & $\begin{array}{l}1.5 \mathrm{~km} \text { below } 50 \mathrm{~km} \\
6 \mathrm{~km} \text { for the mesosphere }\end{array}$ \\
\hline Number of samples & $\sim 1630$ scans per day & $\sim 900$ scans per day \\
\hline Nominal data sampling & $\sim 100$ scans per orbit & $\sim 60$ scans per orbit \\
\hline
\end{tabular}

In this paper, we employ the data assimilation technique developed for other Arctic winters by Rösevall et al. (2007a, b, 2008) to investigate the ozone depletion in the 2009/2010 winter using SMILES ozone data. Other similar studies have used various models and assimilation methods (El Amraoui et al., 2008; Jackson and Orsolini, 2008; Søvde et al., 2011). One advantage of data assimilation is that it allows us to optimally use all measurements and is useful for interpolating or extrapolating the ozone distributions when and where no measurements are available. In this study we have used the DIAMOND assimilation model developed by Rösevall et al. (2007b) to produce active and passive tracer fields. However, because it is a two-dimensional model, Rösevall et al. (2007a, b, 2008) needed to account for the effect of the diabatic descent inside the vortex a posteriori. Thus we have implemented a new vertical transport scheme that continuously accounts for the descent rather than an a posteriori correction. Ozone observed by SMR is analysed for comparison. This paper is structured as follows. Sections 2 and 3 describe the measurements and the model, respectively. Section 4 tests the effectiveness of the new vertical transport scheme using the long-lived species $\mathrm{N}_{2} \mathrm{O}$ measured by SMR and then shows the results of the ozone analyses. Finally, we conclude the study in Sect. 5.

\section{Measurement descriptions}

Profiles of ozone were obtained from the SMILES and SMR instruments. Nitrous oxide $\left(\mathrm{N}_{2} \mathrm{O}\right)$ from SMR was used for this study as a tracer of transport in the stratosphere due to its long lifetime for checking the dynamics in the model.

\subsection{SMILES}

SMILES observed atmospheric limb emissions from the ISS flying at an altitude of $\sim 340-360 \mathrm{~km}$. It vertically scanned the tangent heights of $\sim-20-120 \mathrm{~km}$ with an antenna fieldof-view of $\sim 3 \mathrm{~km}$. A single spectrum was obtained with a data integration time of $0.47 \mathrm{~s}$, and one vertical scan took
$53 \mathrm{~s}$ including the calibration data acquisition. About 1630 scans were obtained per day. Because the ISS has a non-sunsynchronous orbit, the local time of SMILES measurement location evolved over $24 \mathrm{~h}$ after approximately 1 month.

SMILES operated in three frequency bands: 624.32$625.52 \mathrm{GHz}$ (band A), 625.12-626.32 GHz (band B) and 649.12-650.32 GHz (band C). Bands A and B contain the emission line of ozone at $625.371 \mathrm{GHz}$. The measurements are spectrally resolved with an Acousto-Optical Spectrometer (AOS) which has a bandwidth of $1.2 \mathrm{GHz}$ and a resolution of 1.2 MHz. Since SMILES only had two AOSs, the bands were observed on a time-sharing basis. The measurement noise of SMILES is as low as $<0.7 \mathrm{~K}$ (for a single AOS channel and a single spectrum) due to the low noise performance of the superconductor-insulator-superconductor (SIS) mixers. See Kikuchi et al. (2010) for further details about the SMILES instrumentation.

We used the ozone data processed by the NICT level-2 chain version 2.1.5. This level-2 algorithm employs a leastsquares method with a priori regularization (e.g. Rodgers, 2000) as described by Baron et al. (2011). The SMILES NICT ozone data were validated in Kasai et al. (2013). The SMILES ozone profile covers altitudes from 16 to $90 \mathrm{~km}$ with a resolution of $\sim 3-4 \mathrm{~km}$ in the stratosphere (see Fig. 2 in Kasai et al., 2013). Based on the error analysis and comparison studies, Kasai et al. (2013) reported a systematic error of better than $0.3 \mathrm{ppmv}$ in the stratosphere $(\sim 60-8 \mathrm{hPa})$. The random error for a single ozone profile is as low as $1 \%$ for this altitude region. It is also reported that the data quality of ozone profiles from band B is better than that from band A. Ozone data from both bands are used in this study since no bias exists between ozone from bands A and B (see Kasai et al., 2013). Band A ozone data are only used when data from band B are not available.

\section{$2.2 \operatorname{Odin} / \mathrm{SMR}$}

Odin is a Swedish satellite mission in association with Canada, Finland and France, which was designed for ra- 
dio astronomy and limb sounding of the Earth's middle atmosphere (Murtagh et al., 2002). Odin was launched on 20 February 2001 into a sun-synchronous polar orbit with an inclination of $98^{\circ}$, altitude of $\sim 600 \mathrm{~km}$ and descending and ascending nodes at 6 and $18 \mathrm{~h}$ local solar time, respectively. It carries two different limb sounding instruments, OSIRIS (Optical Spectrograph/InfraRed Imaging System) and SMR (Sub-Millimetre Radiometer). The SMR instrument, described by Frisk et al. (2003), consists of four tunable single-sideband Schottky-diode heterodyne microwave receivers.

The data sets for ozone and $\mathrm{N}_{2} \mathrm{O}$ from SMR used in this paper are products of the stratospheric mode that is operated every other day since April 2007 (every third day previous to this). In the stratospheric observation mode, two of the receivers, covering the bands centred at $501.8 \mathrm{GHz}$ and $544.6 \mathrm{GHz}$, are used for detecting the spectral emission lines of ozone and $\mathrm{N}_{2} \mathrm{O}$. The ozone and $\mathrm{N}_{2} \mathrm{O}$ profiles used in this study are retrieved from emission lines at $501.5 \mathrm{GHz}$ and $502.3 \mathrm{GHz}$, respectively, using the Chalmers version 2.1 retrieval scheme.

The SMR ozone profiles cover the altitude range $\sim 17-$ $50 \mathrm{~km}$ with an altitude resolution of $2.5-3.5 \mathrm{~km}$ and an estimated single-profile precision of $\sim 1.5$ ppmv (Urban et al., 2005a). SMR v2.1 ozone data have been validated against balloon sonde measurements as described in detail by Jones et al. (2007). They show that SMR ozone in the $60-90^{\circ} \mathrm{N}$ latitude band has mixing ratios that are $0.0-0.1 \mathrm{ppmv}$ lower than sonde measurements below $23 \mathrm{~km}$ and a positive bias of SMR ozone $0.1-0.3 \mathrm{ppmv}$ in the 23 to $30 \mathrm{~km}$ range. The validation study (Kasai et al., 2013) shows that SMILES generally gives slightly lower ozone values than SMR at altitudes below $20 \mathrm{hPa}$.

The $\mathrm{N}_{2} \mathrm{O}$ profiles cover altitudes in the range $12-60 \mathrm{~km}$ with an altitude resolution of $\sim 1.5 \mathrm{~km}$. The estimated systematic error is less than 12 ppbv (Urban et al., 2005a). The validation of the $\mathrm{N}_{2} \mathrm{O}$ is reported by Urban et al. (2005b). Further comparisons with the Fourier transform spectrometer (FTS) onboard the Atmospheric Chemistry Experiment (ACE) and the Microwave Limb Sounder (MLS) on the Earth Observing System (EOS) Aura satellite are shown by Strong et al. (2008) and Lambert et al. (2007), respectively. SMR $\mathrm{N}_{2} \mathrm{O}$ agrees with ACE/FTS $\mathrm{N}_{2} \mathrm{O}$ within $7 \%$ between 15 and $30 \mathrm{~km}$ (Strong et al., 2008). And SMR $\mathrm{N}_{2} \mathrm{O}$ v2.2 is larger than MLS $\mathrm{N}_{2} \mathrm{O}$ by $\sim 5 \%$ in the pressure range of $68-4.6 \mathrm{hPa}$ and $10 \%$ larger at $100 \mathrm{hPa}$ (Lambert et al., 2007).

\section{DIAMOND model}

The DIAMOND (Dynamic Isentropic Assimilation Model for OdiN Data) is an off-line wind-driven isentropic transport and assimilation model designed to simulate quasi-horizontal ozone transport in the lower stratosphere with low numerical diffusion. Isentropic off-line wind-driven advection has been implemented using the second-order momentum (SOM) advection scheme (Prather, 1986) which is a mass conservative Eulerian scheme. The idea of the Prather scheme is that by preserving the zero- to second-order moments of the subgrid-scale tracer distribution the quality of the transport is preserved. In this study, the wind fields from the operational analyses of the ECMWF have been used. Advection calculations are performed on separate layers with constant potential temperature (PT) ranging from $400 \mathrm{~K}$ to $1000 \mathrm{~K}$ in $25 \mathrm{~K}$ intervals.

The tracer profiles from SMILES or SMR are sequentially assimilated into the advection model. The assimilation scheme in DIAMOND is described as a variant of the Kalman filter. Details of the assimilation scheme can be found in Rösevall et al. (2007b).

\subsection{Cross-isentropic transport}

Under adiabatic conditions, PT is conservative in dry air and thus the air parcels normally move on a constant PT surface. The descent of air in the polar vortex caused by radiative cooling during polar night had not been taken into account in the previous model version. It is, however, necessary for a correct evaluation of ozone loss.

For a flow field $(u, v, w)$, the advection equation of a (passive or active) tracer $\Psi(x, y, \Theta, t)$ at given horizontal coordinates $x$ and $y$, vertical coordinate in potential temperature $\Theta$ and time $t$ in an Eulerian coordinate system is

$$
\frac{\partial \psi}{\partial t}=-u \frac{\partial \psi}{\partial x}-v \frac{\partial \psi}{\partial y}-w \frac{\partial \psi}{\partial \Theta} .
$$

Here, $u$ and $v$ are the horizontal wind speeds and $w$ is the vertical component of air mass advection with units of $\mathrm{Kd}^{-1}$. As we mentioned previously, DIAMOND employs the SOM method to solve the first and second terms in the right-hand side of Eq. (1). On the other hand, to account for the descent we implemented a simple vertical transport scheme into DIAMOND. The following equation is the one-dimensional first-order upstream method implemented into the model:

$$
\begin{aligned}
& \frac{(\Psi(\Theta, t+\Delta t)-\Psi(\Theta, t))}{d t}=w \frac{(\Psi(\Theta-\Delta \Theta, t)-\Psi(\Theta, t))}{d \Theta}, \\
& \Psi(\Theta, t+\Delta t)=\Psi(\Theta, t)\left(1-w \frac{d t}{d \Theta}\right) \\
& +\Psi(\Theta-\Delta \Theta, t) w \frac{d t}{d \Theta} .
\end{aligned}
$$

The first-order upstream method often produces numerical diffusion. In order to avoid this, it is at least necessary to satisfy the condition

$$
\frac{\Delta \Theta}{\Delta t}>C
$$

where $\Delta \Theta, \Delta t$ and $C$ represent the grid interval, the time step and the speed of the phenomenon, respectively. The $\Delta \Theta / \Delta t$ 
Table 2. Description of the calculations.

\begin{tabular}{ll}
\hline Condition & Value \\
\hline Time period & $2009-12-01-2010-03-31$ \\
Initialization & 1 month $(2009-11-01-2009-12-01)$ \\
Altitude range (EPT) & $450 \mathrm{~K}-900 \mathrm{~K}(25 \mathrm{~K}$ resolution $)$ \\
Measurement response & $\geq 0.85$
\end{tabular}

in the model $\left(=2.5 \mathrm{~K} \mathrm{~min}^{-1}\right)$ is much larger than the general descent rate inside the polar vortex $\left(\sim 1 \mathrm{~K} \mathrm{~d}^{-1}\right)$, and therefore the first-order upstream method can be used satisfactorily. It is also important to have a sufficiently small separation of the layers to obtain a good representation of the descent.

To quantify the vertical transport, we used the diabatic heating rate $Q\left(\mathrm{~K} \mathrm{~s}^{-1}\right)$ derived from SLIMCAT 3-D chemical transport model calculations (Chipperfield, 2006). The vertical velocity $w$ was calculated as

$w=\left(\frac{\Theta}{T}\right) \cdot Q$,

where $T$ is the absolute temperature.

\section{Results}

\subsection{Dynamics of the Arctic winter 2009-2010}

In order to test the performance of the model and study the dynamics of this winter, we modelled stratospheric $\mathrm{N}_{2} \mathrm{O}$ fields by assimilation of SMR $\mathrm{N}_{2} \mathrm{O}$. A summary of the calculations is given in Table 2. Initialization (i.e. the spin-up calculations with assimilation) for 1 month prior to the investigation period (from 1 December to $31 \mathrm{March}$ ) is required to ensure the accuracy of the initial model field. In order to remove contamination by erroneous observations, the SMR data are used only if the measurement response is larger than 0.85 . The measurement response, the sum of the elements of the rows of the averaging kernel matrix, gives the contribution of the measurement to the retrieved information. To reduce any boundary condition problems realistic tracer fields are required. These are used as buffer layers to feed the vertical transport scheme. Note that the measurement response especially for SMR $\mathrm{N}_{2} \mathrm{O}$ is generally less than 0.7 at lower altitudes $(<450 \mathrm{~K})$. Therefore, we relaxed the measurement response threshold to 0.7 for the boundary layers. In the results, we only show the output of the model from $450 \mathrm{~K}$ to $900 \mathrm{~K}$ to avoid boundary effects. The uncertainty of the DIAMOND model due to imperfections in the transport scheme and/or unimplemented chemical processes has to be considered. We set the initial error fields to $30 \%$ of the initial field of the species, which corresponds to the standard variation of the 40-day prediction without assimilations. The error field grows linearly to this value in 40 days if no measurements are available.
Figure 4 shows the model results for $\mathrm{N}_{2} \mathrm{O}$ and the corresponding error fields at $600 \mathrm{~K}$. The polar vortex is clearly seen as the area where the volume mixing ratio of $\mathrm{N}_{2} \mathrm{O}$ is low. In the maps the EQL of $70^{\circ} \mathrm{N}$, which is used as the vortex boundary, is drawn as the black contour line. The white contour lines denote the Lait modified potential vorticity of $38 \mathrm{PVU}\left(1 \mathrm{PVU}=1 \times 10^{-6} \mathrm{~K} \mathrm{~m}^{2} \mathrm{~kg}^{-1} \mathrm{~s}^{-1}\right)$ (Lait, 1994). The modified potential vorticity refers to the reference level $475 \mathrm{~K}$. The potential vorticity of $38 \mathrm{PVU}$ is also used for the vortex boundary in other studies (Sonkaew et al., 2013; Hommel et al., 2014). The polar vortex was formed at the beginning of December and stayed at high latitudes for 2 weeks (DOY -31 to -15 ) then distorted and split into two parts caused by changes in the wind fields due to a minor SSW in the middle of December $(\sim-15$ DOY). The two separate vortices combined by 17 December. Kuttippurath and Nikulin (2012) have given a detailed analysis of these processes by using the potential vorticity. Our $\mathrm{N}_{2} \mathrm{O}$ results are consistent with their findings. After that, the vortex stayed cold and remained pole centred until the major SSW occurred at the end of January 2010 (e.g. Dörnbrack et al., 2012; Kuttippurath and Nikulin, 2012). This period shows the lowest temperatures of this winter at potential temperature of $500 \mathrm{~K}$ (see Fig. 1). The major SSW changed the wind field again: massive inflow of air from the Pacific forced the vortex to move to middle latitudes with flattening over Eurasia (see for example the Odin/SMR quick look at http://www.rss.chalmers. se/ jo/SMRquicklook/Qsmr-2-1/N2O_5018/gm/). Furthermore, the vortex again split after 10 February. The two parts are reunited on 1 March with entrainment of some extravortex air. The vortex was then relatively stable for some weeks. Finally, when the polar night ended, the vortex broke and the vortex air horizontally mixed with air from outside (Wohltmann et al., 2013).

To illustrate the advection in the DIAMOND model, we derived the vortex mean of $\mathrm{N}_{2} \mathrm{O}$ from the daily fields. Figure 5 shows the mean of the $\mathrm{N}_{2} \mathrm{O}$ volume mixing ratios inside the area where the EQL is equal to or greater than $70^{\circ}$. The solid lines in the figure are calculated from the results of assimilation of SMR $\mathrm{N}_{2} \mathrm{O}$. The two dashed lines, red and blue, are the vortex mean of the fields predicted by the advection model using the initial $\mathrm{N}_{2} \mathrm{O}$ distribution as of $1 \mathrm{De}$ cember with and without vertical transport, respectively. If the vertical transport would be perfectly simulated in the model, the predicted and assimilated results should have the same values. Compared to the predictions from the 2-D advection scheme, the predictions with the vertical transport scheme shows good agreement with the vortex mean assimilated $\mathrm{N}_{2} \mathrm{O}$ field until the final break-up of the vortex. The uncertainty of the mean, plotted as the shaded areas in Fig. 5, is calculated as $\sqrt{\sigma^{2}+\hat{E}^{2}}$. Here $\sigma$ and $\hat{E}$ are the standard deviation of $\mathrm{N}_{2} \mathrm{O}$ inside the vortex and the vortex mean of the error field, respectively. More details of these compo- 

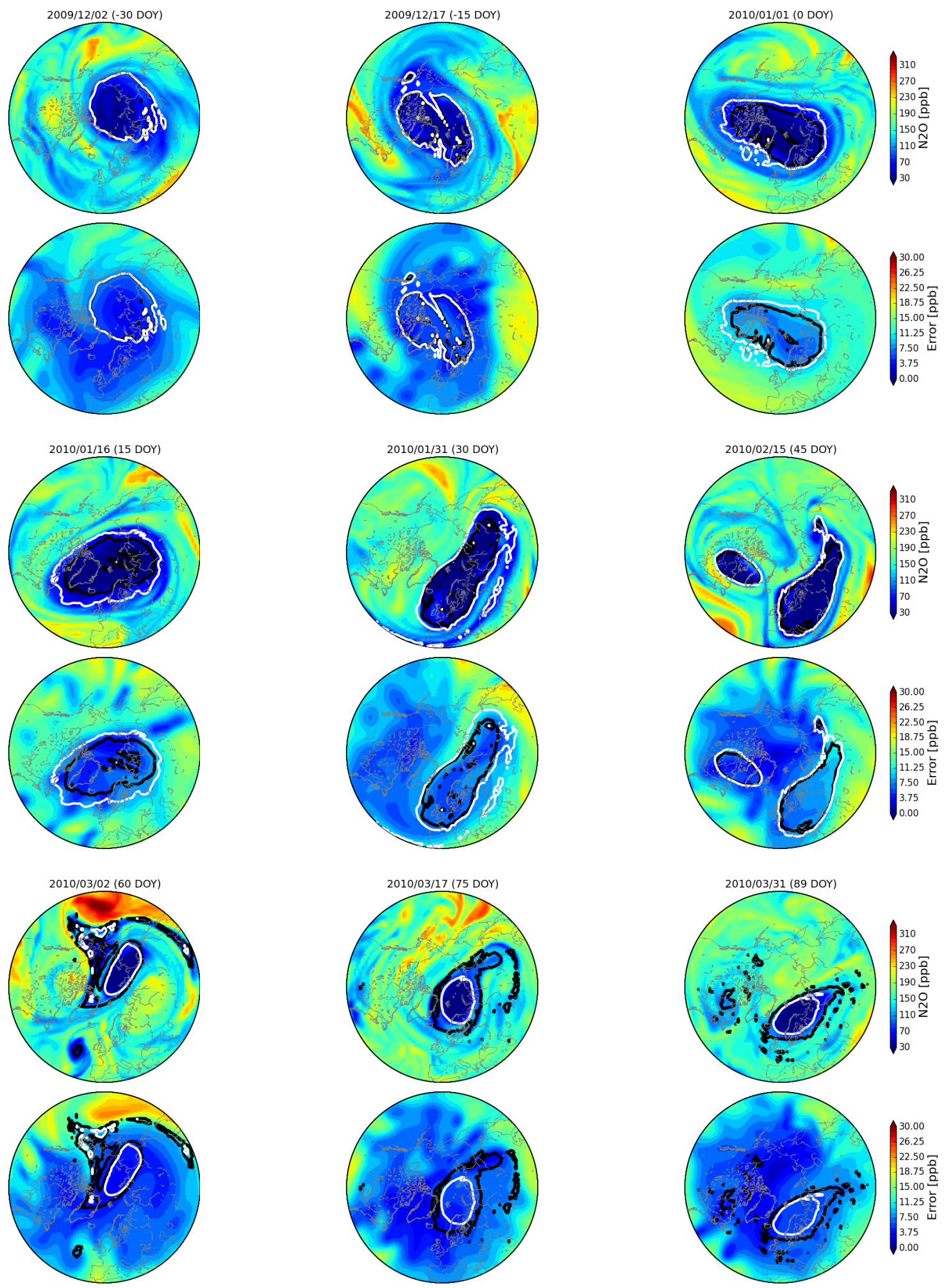

Figure 4. Modelled $\mathrm{N}_{2} \mathrm{O}$ fields with assimilation of SMR data (top) and their error fields (bottom) on selected dates at $600 \mathrm{~K}$ level. The numbers in parentheses indicate the day of year. The contour lines indicate the vortex edge described by two criteria: the black line is based on the equivalent latitude $\left(=70^{\circ} \mathrm{N}\right)$ and the white line is based on Lait's potential vorticity $\left(=38 \mathrm{PVU}=3.8 \times 10^{-6} \mathrm{~K} \mathrm{~m}^{2} \mathrm{~kg}^{-1} \mathrm{~s}^{-1}\right)$. 


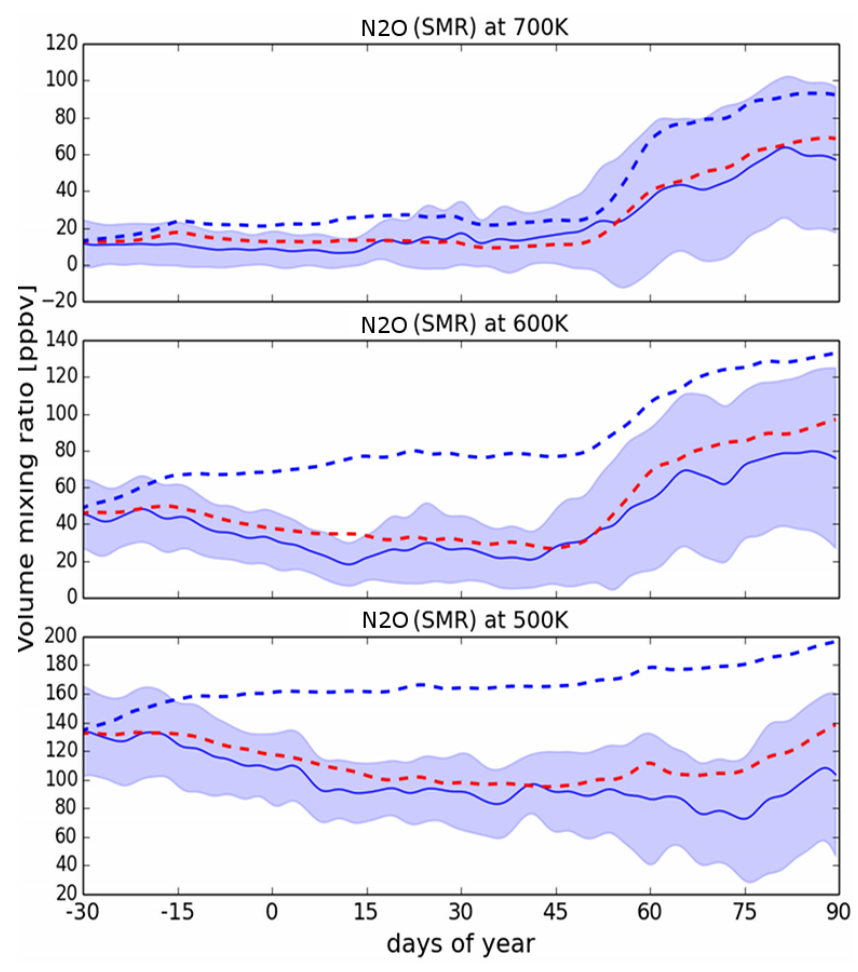

Figure 5. Time series of the vortex mean $\mathrm{N}_{2} \mathrm{O}$ mixing ratio in the DIAMOND model on selected potential temperature levels. The blue solid line shows the average inside the area where the equivalent latitude is $\geq 70^{\circ} \mathrm{N}$, calculated from the assimilated field of Odin $\mathrm{N}_{2} \mathrm{O}$. The dashed lines show vortex means of predictions initiated on December 1, using the 2-D off-line advection model including vertical transport (red) and the advection model without any vertical transport (blue). The shaded area indicates the estimated error (more detail can be seen in Fig. 6). All data are smoothed over 3 days.

nents can be seen in Fig. 6. $\hat{E}$ characterizes the error from the point of view of the instrument. However, the dominant factor in the uncertainties is the variability inside the vortex $(\sigma)$. The temporal evolution of $\sigma$ allows us to assess the contribution of the (mostly horizontal) mixing. At the end of February ( $\sim 50$ DOY), an exponential increase in $\sigma$ occurs caused by the breaking of the vortex and associated mixing. This is particularly noticeable at $600 \mathrm{~K}$.

\subsection{Ozone inside the vortex}

Figures 7 and 8 display maps of the results for ozone from the assimilations of data from SMILES and SMR. The results from the two instruments have similar patterns in the ozone maps although those from SMR exhibit more features and larger variations. The reasons for the differences are the number and quality of the measurements. Specifically, SMR has fewer measurements at lower latitudes because of its orbit and has a higher noise level. The SMILES ozone abundance, as expected due to known biases, was approximately

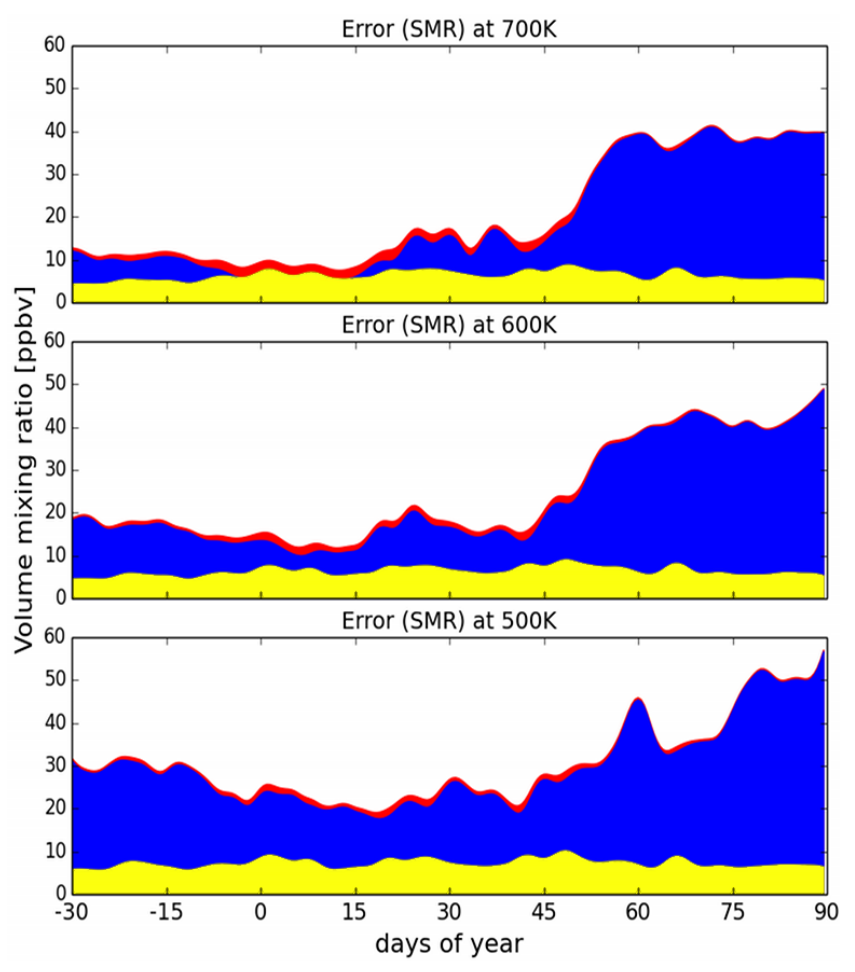

Figure 6. The estimated uncertainty of the vortex mean of $\mathrm{N}_{2} \mathrm{O}$. The blue area shows the standard deviation $(\sigma)$ inside the vortex (EQL $\geq 70$ ). The yellow area shows the vortex mean of the error fields $(\hat{E})$. Finally, the red area indicates the total estimated error, which has been calculated as $\sqrt{\sigma^{2}+\hat{E}^{2}}$ and is shown as uncertainties in Fig. 5. All data are smoothed over 3 days.

0.1 ppmv lower than SMR ozone below $700 \mathrm{~K}$ corresponding to $20 \mathrm{hPa}$ in pressure (see Fig. 20 in Kasai et al., 2013). Another important point is the incomplete coverage of the centre of the vortex for the SMILES assimilation. As noted in the Introduction, SMILES did not observe at higher latitudes than $65^{\circ} \mathrm{N}$. As a result the measurement information on ozone in the polar region is transported from lower latitudes by the model. Thus, when the vortex is stable and well isolated, modelled ozone distributions may deviate from the true atmosphere. This is clearly seen in the SMILES ozone maps at the end of December where higher concentrations compared to earlier are seen inside the vortex due to the descent from higher levels and the lack of any chemical ozone loss processes in the model.

To avoid the effects of large local variations, we have chosen to use the average for the entire vortex for this study. The sampling issues described above are mitigated by employing a weighted average over the vortex as shown in Fig. 9. The weights are given by the estimated model error fields. Note the fact that the vortex mean of the SMILES assimilation thereby emphasizes the contribution near the vortex edge. Vortex averages of ozone from both instruments show similar patterns, especially before the major SSW event at 

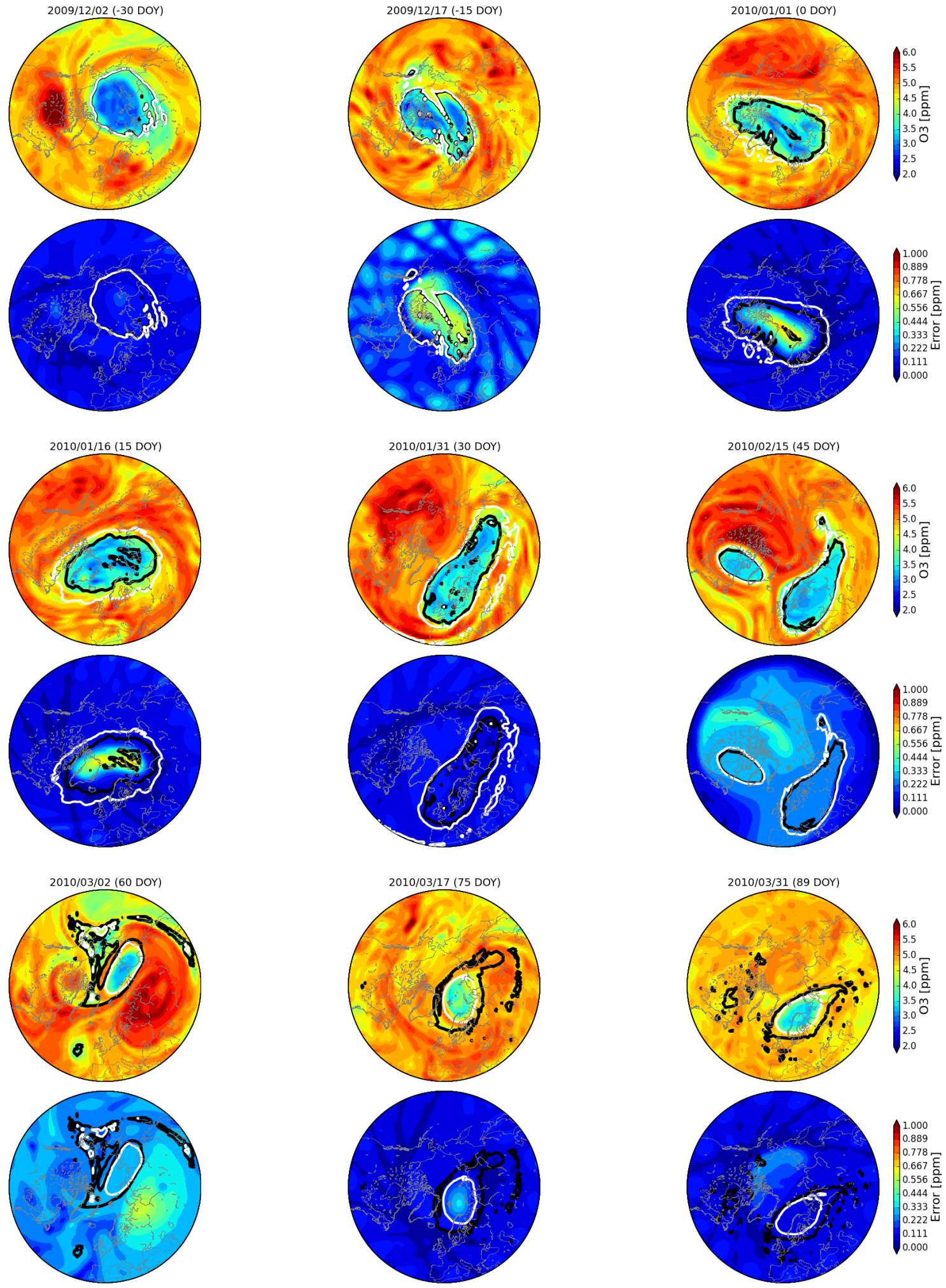

Figure 7. Same as Fig. 4 but for ozone derived from SMILES. 

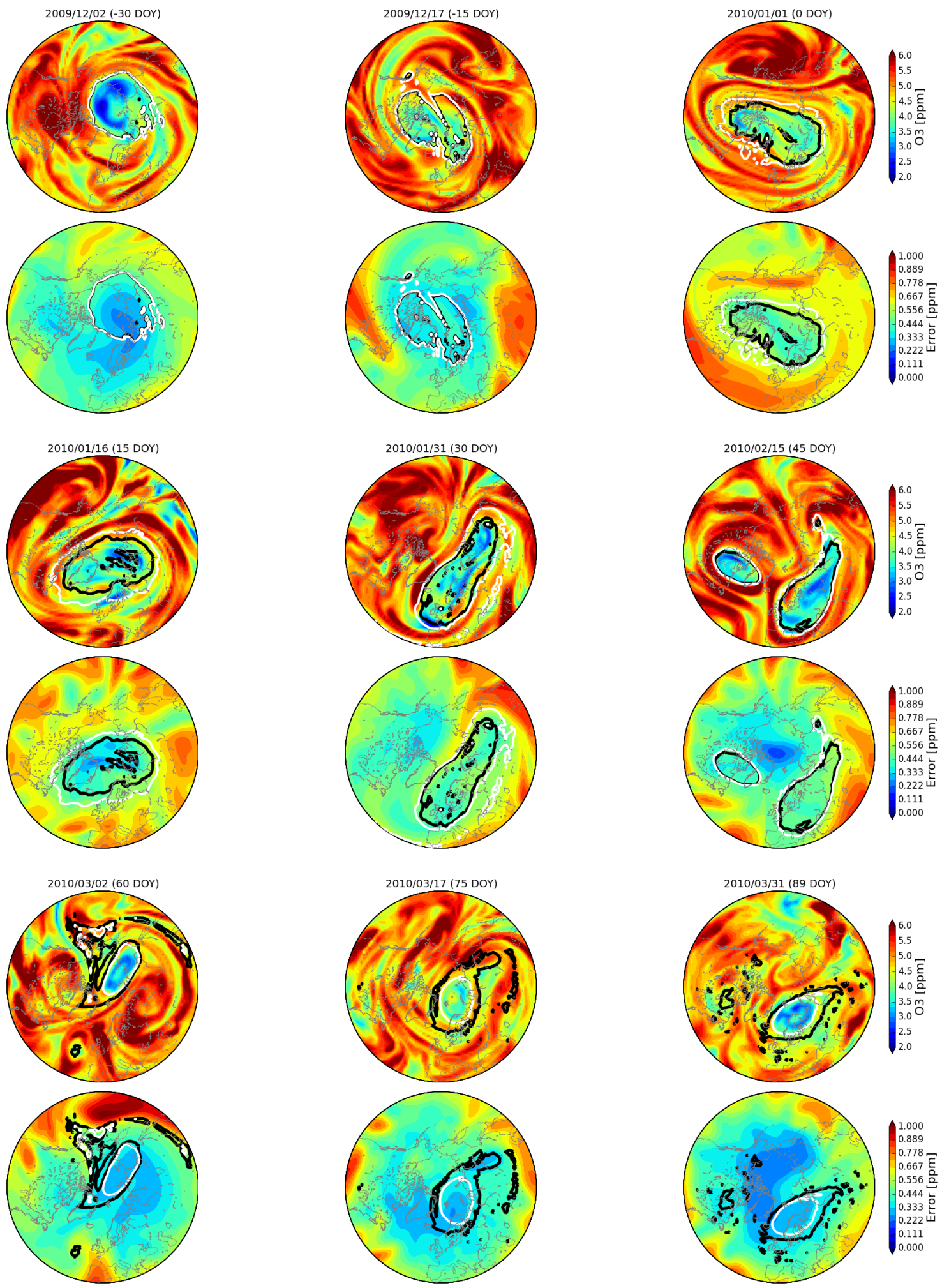

Figure 8. Same as Fig. 4 but for ozone derived from SMR. 

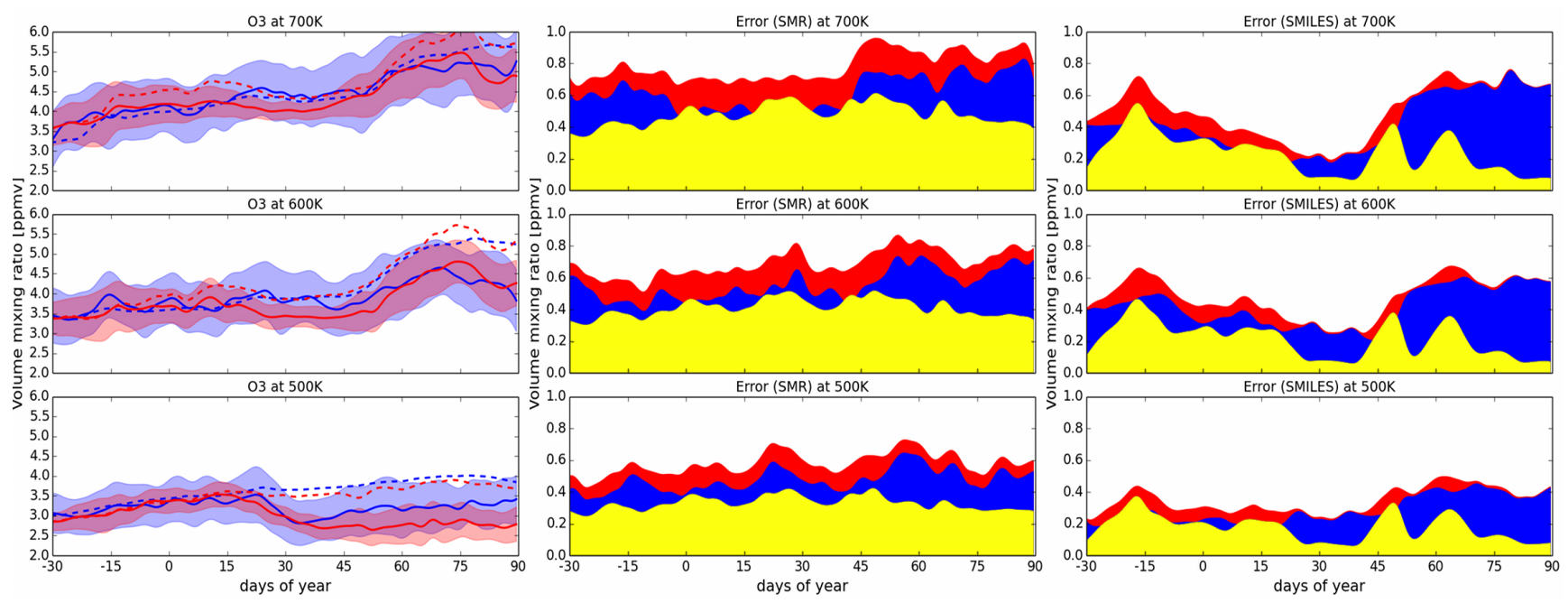

Figure 9. (Left panels) Same as Fig. 5 but for ozone from SMR (blue) and SMILES (red). (Middle panels) Same as Fig. 6 but for ozone from SMR. (Right panels) Same as Fig. 6 but for ozone from SMILES.

the end of January. Uncertainties in Fig. 9 are also calculated using the standard deviation $\sigma$ and the mean of the error field $\hat{E}$ inside the vortex. Since SMR ozone is much noisier, information on the mixing from the vortex internal variation of the ozone fields $\sigma$ are masked by the average error fields $\hat{E}$, while for SMILES the total error reflects the variation inside the vortex especially when there are sufficient measurements available.

\subsection{Ozone loss quantification}

Arctic ozone depletion is estimated by subtracting ozone fields passively transported in the DIAMOND model from the fields with assimilated data. The time evolution of the ozone losses derived from SMILES and SMR are presented in Fig. 10a and b. Ozone losses inferred from the two instruments have similar patterns. The major differences are the loss during the period between 13 January (12 DOY) and 30 January (29 DOY) at $650 \mathrm{~K}$ in the SMILES result and the lower loss value from 17 March (75 DOY) below $500 \mathrm{~K}$ in the SMR result. Because the SMILES results reflect not the pole centre but lower latitudes near the vortex edge, the apparent loss (12-29 DOY, $650 \mathrm{~K})$ in SMILES is due to an overweighting of the losses near the vortex edge. The reason why SMR loss is lower than SMILES below $500 \mathrm{~K}$ is because SMR ozone measurements tend to overestimate ozone at these altitudes due to lower sensitivity/measurement response.

The first significant depletion occurred below $550 \mathrm{~K}$ from 25 January to 7 February (24-37 DOY): this corresponds to the period when the vortex moved towards lower latitudes and becomes exposed to sunlight. The loss rate is approximately $0.06 \mathrm{ppmv} \mathrm{d}^{-1}$ and accumulated loss of $0.8 \mathrm{ppmv}$ can be seen on 7 February (37 DOY) at $500 \mathrm{~K}$. The second ozone loss period took place from the end of February at the heights between $575 \mathrm{~K}$ and $650 \mathrm{~K}$. This continued at a rate of $0.03 \sim 0.04 \mathrm{ppmv} \mathrm{d}^{-1}$. Figure 11 presents the accumulated ozone loss as of 28 February 2010 just before the beginning of the second loss. The first loss occurring below about $550 \mathrm{~K}$ is clearly seen in the profiles of ozone loss as peaks at $500 \mathrm{~K}$. The maximum losses derived by SMILES and SMR are $1.0 \mathrm{ppmv}$ and $0.7 \mathrm{ppmv}$ at $525 \mathrm{~K}$, respectively. Figure 12 shows on the other hand accumulated loss profiles as of 31 March. The loss values below $550 \mathrm{~K}$ for both instruments are almost the same as those on 28 February. However, the loss profiles are higher than on 28 February at most altitudes with the maximum values of $1.1 \mathrm{ppmv}$ (SMILES) and $1.3 \mathrm{ppmv}$ (SMR) at $600 \mathrm{~K}$. Ozone loss as estimated from SMILES is slightly larger at most levels. It is proposed that the difference in ozone loss between the two instruments is a result of sampling differences. SMILES captures ozone changes near the vortex edge where the area has been more exposed to sunlight while SMR on the other hand represents the loss at the centre of the vortex because of its orbit.

The initial loss from 25 January below $550 \mathrm{~K}$ can be explained using the classical mechanism related to heterogeneous reactions on PSCs and the chlorine catalytic cycle (Solomon, 1988). From mid-December until the middle of January, the temperature inside the vortex was cold enough to form PSC (Figs. 10f, $\mathrm{g}$ and $\mathrm{h}$ ). Vortex average $\mathrm{ClO}$ in daytime and nighttime is also presented in the figure panels (Fig. 10c and d). Here, $\mathrm{ClO}$ profiles have been retrieved from the frequency band centred at $501.8 \mathrm{GHz}$ of SMR (Urban et al., 2005a). To group $\mathrm{ClO}$ into day and nighttime, we used solar zenith angles (SZA) of $<90^{\circ}$ and $>95^{\circ}$ as limits to avoid the twilight. Since the partitioning of $\mathrm{ClO} / \mathrm{Cl}_{2} \mathrm{O}_{2}$ is temperature dependent, the enhancement of nighttime $\mathrm{ClO}$ at the end of January is the result of thermal decomposition 
(a) Ozone loss SMR 501GHz

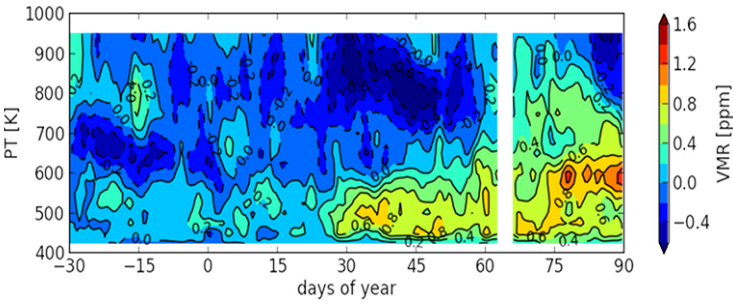

(c) $\mathrm{ClO}$ (daytime) $\mathrm{SMR} 501 \mathrm{GHz}$

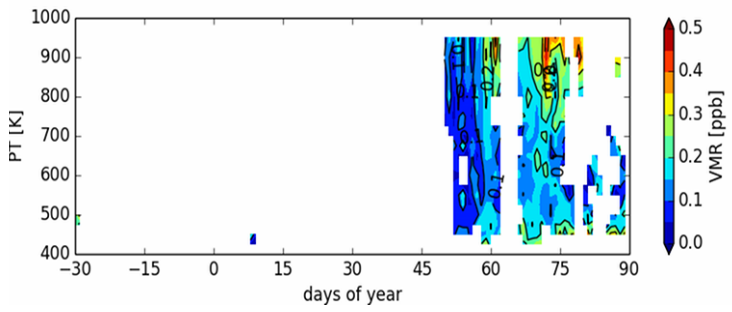

(e) Cumulative sun exposure

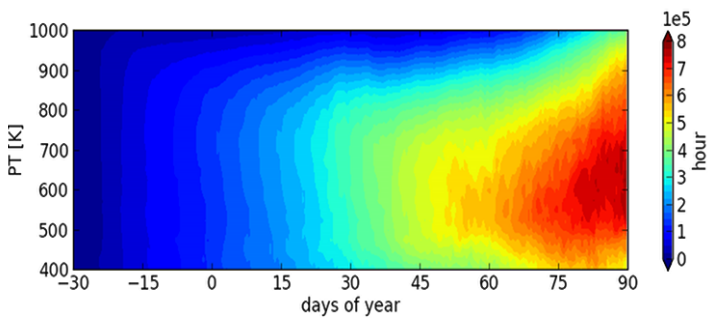

(g) Area with temperatures below 195K

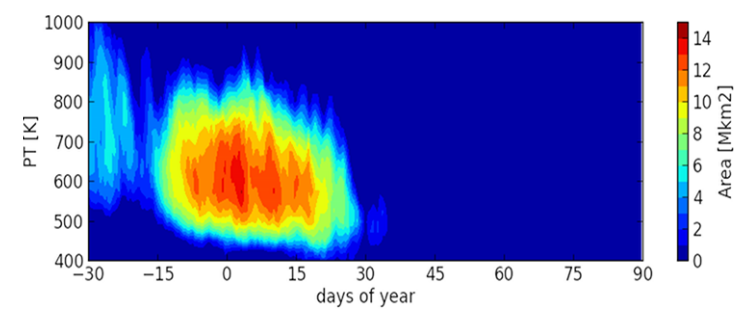

(b) Ozone loss SMILES

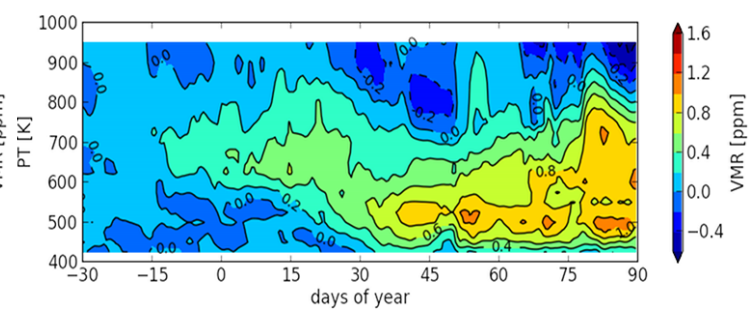

(d) $\mathrm{ClO}$ (nighttime) $\mathrm{SMR} 501 \mathrm{GHz}$

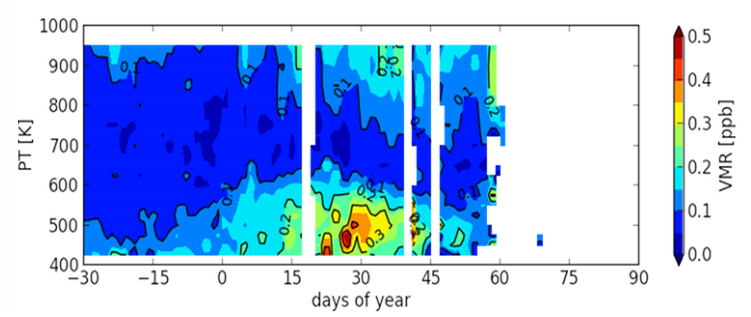

(f) Minimum ECMWF temperature

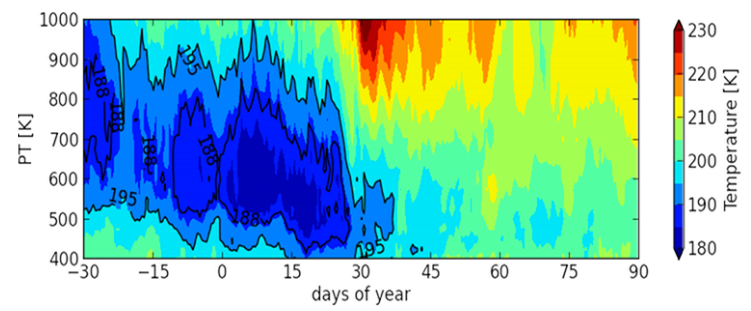

(h) Area with temperatures below $188 \mathrm{~K}$

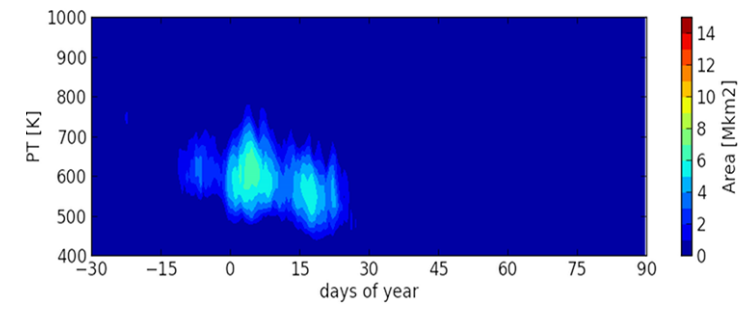

Figure 10. Vortex averages of several parameters in the area where equivalent latitudes are larger than $70^{\circ}$ as a function of time (days from 1 January 2010) and isentropic levels between $400 \mathrm{~K}$ and $1000 \mathrm{~K}$. (a, b) Vortex mean ozone loss derived from SMR and SMILES, respectively. (c, d) Vortex mean $\mathrm{ClO}$ retrieved from SMR in daytime and nighttime, respectively. (e) Cumulative solar exposure time of the polar vortex. (f) Minimum air temperature inside the vortex derived from ECMWF. (g, h) Areas where the temperature is below $T_{\mathrm{NAT}}$ and $T_{\text {ice }}$, respectively.

of $\mathrm{Cl}_{2} \mathrm{O}_{2}$. The peak of $\mathrm{ClO}$ at $475 \mathrm{~K}$ on 28-29 January corresponds to the rise in temperatures after the SSW. On the other hand, the nighttime $\mathrm{ClO}$ increased from 16 December $(-15$ DOY) in advance of the ozone depletion below $500 \mathrm{~K}$ with $0.1 \mathrm{ppbv}$ is due to chlorine activation on PSCs. The average of $\mathrm{ClO}$ during the period from 16 January (15 DOY) to 15 February (45 DOY) is approximately 0.25 ppbv and includes both activation and thermal decomposition.

The upper-level ( $575 \mathrm{~K}$ to $650 \mathrm{~K}$ ) ozone loss from the end of February was not due to chlorine-related destruction. The second loss is correlated with the sun exposure time inside the vortex (shown in Fig. 10e). Nevertheless, the vortex average $\mathrm{ClO}$ is still low at around $600 \mathrm{~K}$ (Fig. 10c). Similar losses were also found in other warm winters (Konopka et al., 2007; Grooß and Müller, 2007; Jackson and Orsolini, 2008; Søvde et al., 2011). Konopka et al. (2007) discussed that the loss around $650 \mathrm{~K}$ in 2002/2003 was induced by the catalytic cycles of $\mathrm{NO}_{\mathrm{x}}$ transported from the mesosphere and lower latitudes. The available result by Kuttippurath et al. (2010) 

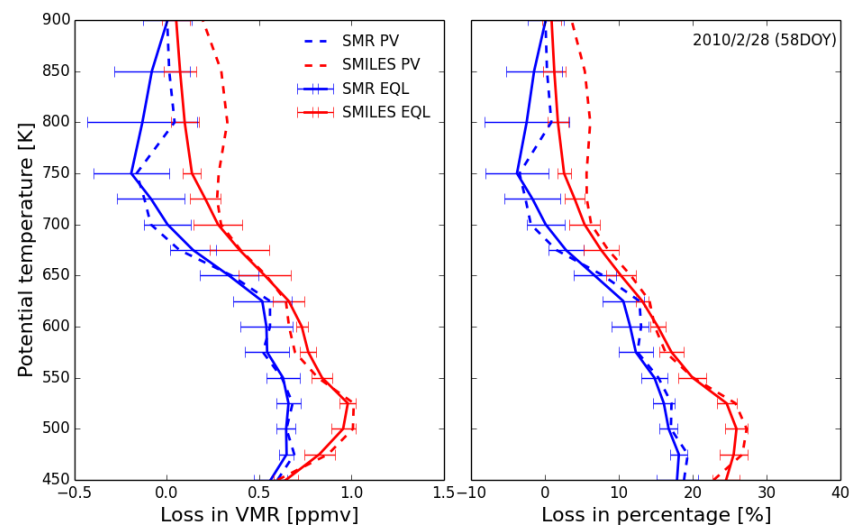

Figure 11. Vertical profiles of accumulated ozone loss as of 28 February 2010 from 1 December 2009. Loss was derived by subtracting the passive ozone from the assimilated ozone. The error bars are given as the standard deviation of derived daily ozone loss inside the vortex for the period of \pm 3 days from 28 February 2010. The left panel shows loss in VMR, and the right panel shows relative losses in percent. The solid lines indicate losses with using the EQL criterion for the vortex edge $\left(\geq 70^{\circ} \mathrm{N}\right)$ while dashed lines show losses obtained using the modified PV criterion ( $\geq 38 \mathrm{PVU})$.

indicates that the $\mathrm{NO}-\mathrm{NO}_{2}$ cycle is dominant in a PSC-free polar stratosphere in the PT range of $600-850 \mathrm{~K}$.

\subsection{Comparison with other studies}

Comparable studies of ozone loss in the winter 2009/2010 based on different analysis methods and measurements were done by Kuttippurath et al. (2010), Wohltmann et al. (2013) and Hommel et al. (2014). The inferred loss of SMR ozone agrees with loss simulated using the chemical transport model ATLAS by Wohltmann et al. (2013). They find cumulative ozone losses of $0.8-0.9 \mathrm{ppmv}$ at $500 \mathrm{~K}$ until $2010 / 03 / 30$ based on a $68.5^{\circ} \mathrm{N}$ equivalent latitude criterion. Values for SMR in Fig. 12 are $0.5-0.8$ depending on the vortex criterion $\left(70^{\circ} \mathrm{N}\right.$ EQL and $\left.38 \mathrm{PVU}\right)$. SMILES losses are larger at this level $(0.8-1.3$ ppmv). Ozone loss derived from MLS presented by Wohltmann et al. (2013) agrees with the model results. Kuttippurath et al. (2010) only quantify ozone loss until the end of February because of the tracer uncertainties after the major warming while other studies continued the analyses during March. The maximum loss around $550 \mathrm{~K}$ derived from their model simulation is $1.1 \mathrm{ppmv}$ at the end of February but the corresponding MLS loss is $1.7 \mathrm{ppmv}$ which is larger than loss derived from MLS data by Wohltmann et al. (2013) (1.4 ppmv at $550 \mathrm{~K}$ for the end of March). MLS loss at these levels is larger than our estimations based on SMILES and SMR ozone. For comparison, the loss derived from SCIAMACHY observations by Hommel et al. (2014) in a layer of $475-525 \mathrm{~K}$ is of the order of $1 \mathrm{ppmv}$ which is roughly consistent with our results. Note that Hommel et al. (2014) used the 38PVU criterion for defining the vortex edge.

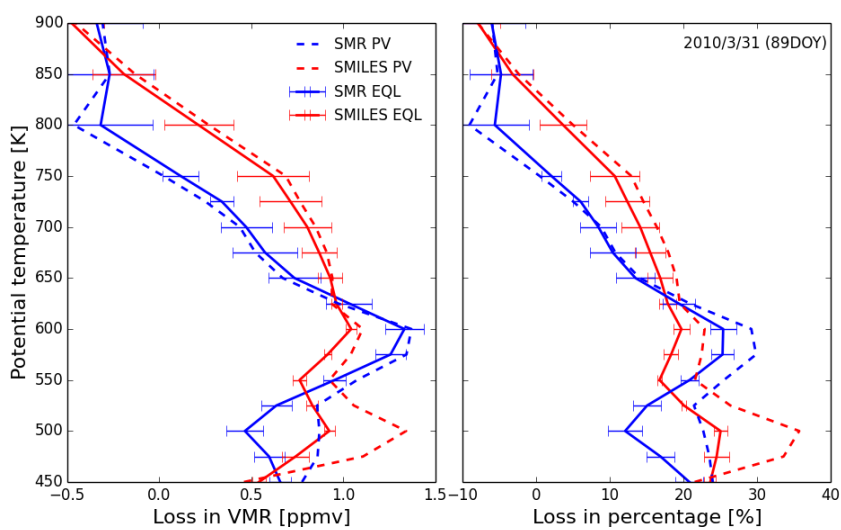

Figure 12. Same as Fig. 11 but for 31 March 2010.

Considering the potential temperature range of $600-$ $650 \mathrm{~K}$, our study finds cumulative ozone loss until 31 March 2010 of about 1.0 and 1.3 ppmv derived from SMILES and SMR, respectively. Wohltmann et al. (2013) find a loss of 1.3-1.4 ppmv in their model result and a loss of $1.7 \mathrm{ppmv}$ in MLS data. The analysis of SCIAMACHY data shows losses of 1-1.5 ppmv in the beginning of April (Hommel et al., 2014).

Plausible explanations for differences are instrument sampling differences and the vertical resolutions of the profile measurements. Other possible reasons are the different criteria for defining the vortex edge. We have tested two different vortex criteria. In addition to using the EQL of $70^{\circ} \mathrm{N}$, the modified PV criterion (38 PVU) applied in Hommel et al. (2014) has been used for quantifying ozone loss. Major differences between ozone loss derived with the two criteria can be seen around $800 \mathrm{~K}$ on 28 February in Fig. 11 and below $550 \mathrm{~K}$ on 31 March in Fig. 12. With the modified PV criterion we obtain roughly 0.2 ppmv higher loss above $800 \mathrm{~K}$ on 28 February in Fig. 11. In this height range, $\mathrm{N}_{2} \mathrm{O}$ has large variations and the standard deviation of ozone inside the vortex (not shown) is large for the period of the vortex separation. However, there are no differences in ozone loss below $700 \mathrm{~K}$ where ozone loss generally occurs. For example, Fig. 4 compares the two vortex edge criteria at the $600 \mathrm{~K}$ level. A good agreement of the two criteria can be seen until the end of February, but differences are found in March. Differences of ozone loss on 31 March at $500 \mathrm{~K}$ are approximately 0.3 ppmv. It is thus likely that the air near the vortex edge moderates the loss of ozone using the EQL criteria. The losses derived with the two criteria still agree with each other within 10 percentage units.

\section{Conclusions}

Data sets from SMILES and SMR have been used to quantify ozone loss inside the polar vortex for the Arctic winter 2009/2010. The investigation was performed using the 
DIAMOND data assimilation framework. DIAMOND is an off-line wind-driven transport model advecting air on isentropic surfaces into which we introduced the vertical crossisentropic transport. Assimilation of SMR $\mathrm{N}_{2} \mathrm{O}$ was used to verify the cross-isentropic scheme when using SLIMCAT heating rates to calculate the diabatic descent.

We have demonstrated that indeed SMILES measurements combined with a data assimilation technique can be used to study ozone loss even at higher latitudes than $65^{\circ} \mathrm{N}$. Ozone fields from assimilation of SMILES and SMR show similar patterns, although the quality and coverage of measurements caused differences between the ozone fields, especially at lower latitudes. The agreement is also seen in the time evolutions of weighted vortex mean of ozone.

Ozone loss was derived by comparing fields acquired by sequential assimilation with passively transported fields. Significant losses are seen at different altitudes using both SMILES and SMR data and can be explained as follows: (I) Before the major SSW ( $\sim 21$ January), the reasonably stable and isolated polar vortex remained centred around the north pole and cold temperatures allowed the formation of PSCs. (II) The SSW changed the wind field and the inflow of air from the Pacific pushed the vortex out towards middle latitudes. (III) The first rapid ozone depletion occurred below $550 \mathrm{~K}$ mostly close to the vortex edge where the polar night had ended (from 24 January to 7 February). The depletion of $\sim 1.0 \mathrm{ppmv}$ is considered to be a result of $\mathrm{ClO}$ catalytic destruction. (IV) The second loss in the height range $575 \mathrm{~K}$ to $650 \mathrm{~K}$ started from the end of February and continued until the vortex break up. 20-25\% of ozone was removed from this altitude. This loss was induced by the $\mathrm{NO}_{\mathrm{x}}$ reactions (Kuttippurath et al., 2010; Sonkaew et al., 2013). Further study is required to fully understand the mechanisms. The accumulated ozone loss as of 28 February derived from SMILES was higher than that from SMR by $<10 \%$ and it can be attributed to loss occurring near the vortex edge. The initial peak of ozone loss at lower levels was 0.7 ppmv (15$20 \%$ ) at $475 \mathrm{~K}$ for SMR ozone and $1 \mathrm{ppmv}(20-25 \%)$ at $500 \mathrm{~K}$ for SMILES ozone, respectively. The second loss at $600 \mathrm{~K}$ was $0.8 \mathrm{ppmv}(15-20 \%)$ for both instruments. Ozone loss derived using the modified PV criterion agrees with the loss using the EQL criterion until the end of February below $700 \mathrm{~K}$. Loss with the modified PV criterion on 31 March 2010 is approximately 0.3 ppmv higher at $500 \mathrm{~K}$. Our estimation shows lower ozone loss than losses derived from other studies using MLS and SCIAMACHY measurements.

Acknowledgements. We thank Martyn Chipperfield and Wuhu Feng at the University of Leeds for providing the diabatic heating rate for this study and the Swedish National Space Board (SNSB) for funding.

Edited by: C. von Savigny

\section{References}

Baron, P., Urban, J., Sagawa, H., Möller, J., Murtagh, D. P., Mendrok, J., Dupuy, E., Sato, T. O., Ochiai, S., Suzuki, K., Manabe, T., Nishibori, T., Kikuchi, K., Sato, R., Takayanagi, M., Murayama, Y., Shiotani, M., and Kasai, Y.: The Level 2 research product algorithms for the Superconducting Submillimeter-Wave Limb-Emission Sounder (SMILES), Atmos. Meas. Tech., 4, 2105-2124, doi:10.5194/amt-4-2105-2011, 2011.

Chipperfield, M. P.: New version of the TOMCAT/SLIMCAT offline chemical transport model: Intercomparison of stratospheric tracer experiments, Q. J. Roy. Meteor. Soc., 132, 1179-1203, doi:10.1256/qj.05.51, 2006.

Dörnbrack, A., Pitts, M. C., Poole, L. R., Orsolini, Y. J., Nishii, K., and Nakamura, H.: The 2009-2010 Arctic stratospheric winter general evolution, mountain waves and predictability of an operational weather forecast model, Atmos. Chem. Phys., 12, 36593675, doi:10.5194/acp-12-3659-2012, 2012.

El Amraoui, L., Semane, N., Peuch, V. H., and Santee, M. L.: Investigation of dynamical processes in the polar stratospheric vortex during the unusually cold winter 2004/2005, Geophys. Res. Lett., 35, L03803, doi:10.1029/2007GL031251, 2008.

Frisk, U., Hagström, M., Ala-Laurinaho, J., Andersson, S., Berges, J. C., Chabaud, J. P., Dahlgren, M., Emrich, A., Florén, H. G., Florin, G., Fredrixon, M., Gaier, T., Haas, R., Hirvonen, T., Hjalmarsson, Å., Jakobsson, B., Jukkala, P., Kildal, P. S., Kollberg, E., Lassing, J., Lecacheux, A., Lehikoinen, P., Lehto, A., Mallat, J., Marty, C., Michet, D., Narbonne, J., Nexon, M., Olberg, M., Olofsson, A. O. H., Olofsson, G., Origné, A., Petersson, M., Piironen, P., Pons, R., Pouliquen, D., Ristorcelli, I., Rosolen, C., Rouaix, G., Räisänen, A. V., Serra, G., Sjöberg, F., Stenmark, L., Torchinsky, S., Tuovinen, J., Ullberg, C., Vinterhav, E., Wadefalk, N., Zirath, H., Zimmermann, P., and Zimmermann, R.: The Odin satellite, A\&A, 402, L27-L34, doi:10.1051/00046361:20030335, 2003.

Grooß, J. U. and Müller, R.: Simulation of ozone loss in Arctic winter 2004/2005, Geophys. Res. Lett., 34, L05804, doi:10.1029/2006GL028901, 2007.

Hommel, R., Eichmann, K. U., Aschmann, J., Bramstedt, K., Weber, M., von Savigny, C., Richter, A., Rozanov, A., Wittrock, F., Khosrawi, F., Bauer, R., and Burrows, J. P.: Chemical ozone loss and ozone mini-hole event during the Arctic winter 2010/2011 as observed by SCIAMACHY and GOME-2, Atmos. Chem. Phys., 14, 3247-3276, doi:10.5194/acp-14-3247-2014, 2014.

Jackson, D. R. and Orsolini, Y. J.: Estimation of Arctic ozone loss in winter 2004/05 based on assimilation of EOS MLS and SBUV/2 observations, Q. J. Roy. Meteor. Soc., 134, 1833-1841, doi:10.1002/qj.316, 2008.

Jones, A., Murtagh, D., Urban, J., Eriksson, P., and Rosevall, J.: Intercomparison of Odin/SMR ozone measurements with MIPAS and balloonsonde data, Can. J. Phys., 85, 1111-1123, 2007.

Kasai, Y., Sagawa, H., Kreyling, D., Dupuy, E., Baron, P., Mendrok, J., Suzuki, K., Sato, T. O., Nishibori, T., Mizobuchi, S., Kikuchi, K., Manabe, T., Ozeki, H., Sugita, T., Fujiwara, M., Irimajiri, Y., Walker, K. A., Bernath, P. F., Boone, C., Stiller, G., von Clarmann, T., Orphal, J., Urban, J., Murtagh, D., Llewellyn, E. J., Degenstein, D., Bourassa, A. E., Lloyd, N. D., Froidevaux, L., Birk, M., Wagner, G., Schreier, F., Xu, J., Vogt, P., Trautmann, T., and Yasui, M.: Validation of stratospheric and mesospheric ozone observed by SMILES from International Space 
Station, Atmos. Meas. Tech., 6, 2311-2338, doi:10.5194/amt-62311-2013, 2013.

Khosrawi, F., Urban, J., Pitts, M. C., Voelger, P., Achtert, P., Kaphlanov, M., Santee, M. L., Manney, G. L., Murtagh, D., and Fricke, K. H.: Denitrification and polar stratospheric cloud formation during the Arctic winter 2009/2010, Atmos. Chem. Phys., 11, 8471-8487, doi:10.5194/acp-11-8471-2011, 2011.

Kikuchi, K., Nishibori, T., Ochiai, S., Ozeki, H., Irimajiri, Y., Kasai, Y., Koike, M., Manabe, T., Mizukoshi, K., Murayama, Y., Nagahama, T., Sano, T., Sato, R., Seta, M., Takahashi, C., Takayanagi, M., Masuko, H., Inatani, J., Suzuki, M., and Shiotani, M.: Overview and early results of the Superconducting Submillimeter-Wave Limb-Emission Sounder (SMILES), J. Geophys. Res., 115, D23306, doi:10.1029/2010JD014379, 2010.

Konopka, P., Engel, A., Funke, B., Müller, R., Grooß, J.U., Günther, G., Wetter, T., Stiller, G., von Clarmann, T., Glatthor, N., Oelhaf, H., Wetzel, G., López-Puertas, M., Pirre, M., Huret, N., and Riese, M.: Ozone loss driven by nitrogen oxides and triggered by stratospheric warmings can outweigh the effect of halogens, J. Geophys. Res., 112, D05105, doi:10.1029/2006JD007064, 2007.

Kuttippurath, J. and Nikulin, G.: A comparative study of the major sudden stratospheric warmings in the Arctic winters 2003/2004-2009/2010, Atmos. Chem. Phys., 12, 8115-8129, doi:10.5194/acp-12-8115-2012, 2012.

Kuttippurath, J., Godin-Beekmann, S., Lefèvre, F., and Goutail, F.: Spatial, temporal, and vertical variability of polar stratospheric ozone loss in the Arctic winters 2004/2005-2009/2010, Atmos. Chem. Phys., 10, 9915-9930, doi:10.5194/acp-10-9915-2010, 2010.

Lait, L. R.: An Alternative Form for Potential Vorticity, J. Atmos. Sci., 51, 1754-1759, doi:10.1175/15200469(1994)051<1754:AAFFPV>2.0.CO;2, 1994.

Lambert, A., Read, W. G., Livesey, N. J., Santee, M. L., Manney, G. L., Froidevaux, L., Wu, D. L., Schwartz, M. J., Pumphrey, H. C., Jimenez, C., Nedoluha, G. E., Cofield, R. E., Cuddy, D. T., Daffer, W. H., Drouin, B. J., Fuller, R. A., Jarnot, R. F., Knosp, B. W., Pickett, H. M., Perun, V. S., Snyder, W. V., Stek, P. C., Thurstans, R. P., Wagner, P. A., Waters, J. W., Jucks, K. W., Toon, G. C., Stachnik, R. A., Bernath, P. F., Boone, C. D., Walker, K. A., Urban, J., Murtagh, D., Elkins, J. W., and Atlas, E.: Validation of the Aura Microwave Limb Sounder middle atmosphere water vapor and nitrous oxide measurements, J. Geophys. Res., 112, D24S36, doi:10.1029/2007JD008724, 2007.

Murtagh, D., Frisk, U., Merino, F., Ridal, M., Jonsson, A., Stegman, J., Witt, G., Eriksson, P., Jiménez, C., Megie, G., Noë, J. d. 1., Ricaud, P., Baron, P., Pardo, J. R., Hauchcorne, A., Llewellyn, E. J., Degenstein, D. A., Gattinger, R. L., Lloyd, N. D., Evans, W. F., McDade, I. C., Haley, C. S., Sioris, C., Savigny, C. v., Solheim, B. H., McConnell, J. C., Strong, K., Richardson, E. H., Leppelmeier, G. W., Kyrölä, E., Auvinen, H., and Oikarinen, L.: An overview of the Odin atmospheric mission, Can. J. Phys., 80, 309-319, doi:10.1139/p01-157, 2002.

Prather, M. J.: Numerical Advection by Conservation of Second-Order Moments, J. Geophys. Res., 91, 6671-6681, doi:10.1029/JD091iD06p06671, 1986.

WMO: Scientific Assessment of Ozone Depletion: 2010, Global Ozone Research and Monitoring Project-Report No. 52, 516pp., Geneva, Switzerland, 2011.
Rodgers, C. D.: Inverse methods for atmospheric sounding: Theory and Practice, Series on Atmospheric, Oceanic and Planetary Physics-Vol. 2, Singapore, World Scentic, 2000.

Rösevall, J. D., Murtagh, D. P., and Urban, J.: Ozone depletion in the 2006/2007 Arctic winter, Geophys. Res. Lett., 34, L21809, doi:10.1029/2007GL030620, 2007a.

Rösevall, J. D., Murtagh, D. P., Urban, J., and Jones, A. K.: A study of polar ozone depletion based on sequential assimilation of satellite data from the ENVISAT/MIPAS and Odin/SMR instruments, Atmos. Chem. Phys., 7, 899-911, doi:10.5194/acp-7899-2007, 2007b.

Rösevall, J. D., Murtagh, D. P., Urban, J., Feng, W., Eriksson, P., and Brohede, S.: A study of ozone depletion in the 2004/2005 Arctic winter based on data from Odin/SMR and Aura/MLS, J. Geophys. Res., 113, D13 301, doi:10.1029/2007JD009560, 2008.

Scherhag, R.: Die explosionsartige Stratosphärenerwärmung des Spätwinters 1951/52, Berichte des Deutschen Wetterdienstes, 38, 51-63, 1952.

Solomon, S.: The mystery of the Antarctic “Ozone Hole”, Rev. Geophys., 26, 131-148, doi:10.1029/RG026i001p00131, 1988.

Solomon, S.: Stratospheric ozone depletion: A review of concepts and history, Rev. Geophys., 37, 275-316, doi:10.1029/1999RG900008, 1999.

Sonkaew, T., von Savigny, C., Eichmann, K. U., Weber, M., Rozanov, A., Bovensmann, H., Burrows, J. P., and Grooß, J. U.: Chemical ozone losses in Arctic and Antarctic polar winter/spring season derived from SCIAMACHY limb measurements 2002-2009, Atmos. Chem. Phys., 13, 1809-1835, doi:10.5194/acp-13-1809-2013, 2013.

Søvde, O. A., Orsolini, Y. J., Jackson, D. R., Stordal, F., Isaksen, I. S. A., and Rognerud, B.: Estimation of Arctic O3 loss during winter 2006/2007 using data assimilation and comparison with a chemical transport model, Q. J. Roy. Meteor. Soc., 137, 118-128, doi:10.1002/qj.740, 2011.

Strong, K., Wolff, M. A., Kerzenmacher, T. E., Walker, K. A., Bernath, P. F., Blumenstock, T., Boone, C., Catoire, V., Coffey, M., De Mazière, M., Demoulin, P., Duchatelet, P., Dupuy, E., Hannigan, J., Höpfner, M., Glatthor, N., Griffith, D. W. T., Jin, J. J., Jones, N., Jucks, K., Kuellmann, H., Kuttippurath, J., Lambert, A., Mahieu, E., McConnell, J. C., Mellqvist, J., Mikuteit, S., Murtagh, D. P., Notholt, J., Piccolo, C., Raspollini, P., Ridolfi, M., Robert, C., Schneider, M., Schrems, O., Semeniuk, K., Senten, C., Stiller, G. P., Strandberg, A., Taylor, J., Tétard, C., Toohey, M., Urban, J., Warneke, T., and Wood, S.: Validation of ACE-FTS N2O measurements, Atmos. Chem. Phys., 8, 47594786, doi:10.5194/acp-8-4759-2008, 2008.

Urban, J., Lautié, N., Le Flochmoën, E., Jiménez, C., Eriksson, P., de La Noë, J., Dupuy, E., Ekström, M., El Amraoui, L., Frisk, U., Murtagh, D., Olberg, M., and Ricaud, P.: Odin/SMR limb observations of stratospheric trace gases: Level 2 processing of ClO, N2O, HNO3, and O3, J. Geophys. Res., 110, D14 307, doi:10.1029/2004JD005741, 2005a.

Urban, J., Lautié, N., Le Flochmoën, E., Jiménez, C., Eriksson, P., de La Noë, J., Dupuy, E., El Amraoui, L., Frisk, U., Jégou, F., Murtagh, D., Olberg, M., Ricaud, P., Camy-Peyret, C., Dufour, G., Payan, S., Huret, N., Pirre, M., Robinson, A. D., Harris, N. R. P., Bremer, H., Kleinböhl, A., Küllmann, K., Künzi, K., Kuttippurath, J., Ejiri, M. K., Nakajima, H., Sasano, Y., Sugita, T., Yokota, T., Piccolo, C., Raspollini, P., and Ri- 
dolfi, M.: Odin/SMR limb observations of stratospheric trace gases: Validation of $\mathrm{N}_{2} \mathrm{O}$, J. Geophys. Res., 110, D09301, doi:10.1029/2004JD005394, 2005b.

Wohltmann, I., Wegner, T., Müller, R., Lehmann, R., Rex, M., Manney, G. L., Santee, M. L., Bernath, P., Sumińska-Ebersoldt, O., Stroh, F., von Hobe, M., Volk, C. M., Hösen, E., Ravegnani, F., Ulanovsky, A., and Yushkov, V.: Uncertainties in modelling heterogeneous chemistry and Arctic ozone depletion in the winter 2009/2010, Atmos. Chem. Phys., 13, 3909-3929, doi:10.5194/acp-13-3909-2013, 2013. 